DOI

\title{
АВТОДЕРМОПЛАСТИКА ТА ВАКУУМНА ТЕРАПІЯ РАН У ХВОРИХ НА СИНДРОМ ДІАБЕТИЧНОї СТОПИ
}

\author{
๑П. О. Герасимчук, В. Г. Власенко, А. В. Павлишин, Д. Б. Фіра
}

ДвНЗ «Тернопільський державний медичний університет імені І. Я. Горбачевського МОз України»

РЕЗЮМЕ. На основі обстеження та лікування 142 хворих на ускладнені форми синдрому діабетичної стопи вивчено вплив вакуумної терапії на підготовку ран до автодермопластики. Доведено, що вакуумна терапія ран дозволяє майже вдвічі зменшити число етапних некректомій та скоротити терміни підготовки ран до автодермопластики у хворих з невропатично-інфікованою формою ураження в середньому на $(3,4 \pm 1,2)$ дні, у хворих з ішемічно-гангренозною формою - в середньому на $(3,96 \pm 1,7)$ дні. Це дозволяє в зменшити терміни стаціонарного лікування хворих у середньому на $(4,2 \pm 1,8)$ ліжко-дні, що має не тільки медичне, а і соціальне значення.

КЛЮчОВІ СЛОВА: синдром діабетичної стопи, вакуумна терапія.

Вступ. На сучасному етапі хірургічне лікування гнійно-некротичних уражень нижніх кінцівок у хворих на цукровий діабет (ЦД) залишається актуальною і не до кінця вирішеною проблемою. Розвиток сучасних методів обстеження та удосконалення методик оперативних втручань дозволяють в більшості випадків виконувати радикальні хірургічні обробки і «малі» ампутації у хворих на синдром діабетичної стопи (СДС), які спрямовані на збереження нижньої кінцівки та ії опірної функції $[1,2]$. Але виконання таких втручань призводить до формування великих ранових дефектів, які в умовах метаболічних порушень та спотвореного ранового процесу часто формують хронічні рани (трофічні виразки) [3]. Велика площа ран створює несприятливі умови для самостійного загоєння, що потребує вирішення питання про їх пластичне закриття.

Пластика ран у хворих на СДС місцевими тканинами у 30-50 \% випадків ускладнюється некрозами м'якотканинних клаптів, розвитком нагно$\epsilon$ ь [4]. Тому перевага надається автодермопластиці вільними шкірними клаптями. Даний метод не потребує спеціального обладнання і може широко використовуватися в лікуванні ран у хворих на СДС $[7,8]$.

Підготовка ран до пластичного закриття у хворих на СДС займає тривалий час, з виконанням повторних некректомій та численних перев'язок. Це обумовлює пошук нових методів підготовки ранових дефектів до пластичного закриття. Одним із них $\epsilon$ вакуумна терапія ран, яка ґрунтується на створенні негативного тиску на рановій поверхні. В літературі описані позитивні впливи вакуумної терапії на перебіг ранового процесу, однак лікуванню хворих на СДС цим методом присвячені окремі публікації, які повністю не висвітлюють вказану проблему [10-13], що потребує проведення подальших досліджень.
Мета дослідження. Вивчити вплив вакуумної терапії на підготовку гострих та хронічних ран у хворих з СДС до автодермопластики та ії ролі в приживленні шкірних автодермотрансплантатів.

Матеріал і методи дослідження. Робота ґрунтується на матеріалах комплексного обстеження та лікування 142 хворих на ускладнені форми СДС, які впродовж 2012-2015 рр. перебували на стаціонарному лікуванні в клініці загальної хірургії ДВНЗ «Тернопільський державний медичний університет імені І. Я. Горбачевського МОЗ України» (хірургічне відділення Тернопільської міської комунальної лікарні швидкої допомоги). У всіх пацієнтів було отримано інформовану згоду на запропоновані дослідження та методи лікування.

Серед обстежених хворих чоловіків було 85 (59,9 \%), жінок - 57 (40,1\%), віком від 49 до 67 років. Середній вік пацієнтів склав $(61,8 \pm 4,7)$ роки. Хворих на ЦД легкого ступеня було 21, середньої тяжкості - 82, важкого - 39. Тривалість захворювання коливалась в межах від 7 до 32 років і у середньому складала $(11,8 \pm 4,3)$ роки. Стадія компенсації ЦД при поступленні діагностована у 36 хворих (25,4 \%), субкомпенсації - у 82 (57,7 \%), декомпенсації- у 24 (16,9\%) пацієнтів.

Хворих з невропатично-інфікованою формою (НІФ) СДСбуло 67 (47,2\%), ішемічно-гангренозною (ІГФ) -75 (52,8\%).

За глибиною ураження хворих з І ст. було 18 (12,7 \%), II ст. - 32 (22,5\%), III ст. - 65 (45,8 \%), IV ст. 27 (19,0 \%) (за Мегіт-Вагнером). У дослідження не включали пацієнтів з 0 ступенем (відсутні ранові дефекти), хворих з V ступенем, яким показане проведення первинних високих ампутацій кінцівок, та пацієнтів з хронічною артеріальною недостатністю (ХАН) IV ст.

Залежно від характеру перебігу ранових процесів хворі були поділені на пацієнтів з гострими 
Огляди літератури, оригінальні дослідження, погляд на проблему

гнійно-некротичними процесами - 75 (52,8 \%), та хронічними ранами - 67 (47,2 \%). Серед гострих гнійно-некротичних уражень у хворих діагностували абсцеси, флегмони, вологу або суху гангрену одного або декількох пальців, вологу або суху гангрену дистального відділу стопи. Хронічними вважали рани у пацієнтів з рановими дефектами, які не гоїлися впродовж чотирьох і більше тижнів на тлі адекватної терапії (трофічні виразки, рани після хірургічних втручань на стопі). 3 кожної групи виділено по 8 пацієнтів, яким вакуумну терапію не проводили, вони склали контрольні групи.

Усім хворим проводили комплексне клініколабораторне та інструментальне обстеження. Воно включало детальний збір скарг та анамнезу захворювання і об'єктивне обстеження пацієнтів, що дозволяло діагностувати тип та тяжкість ЦД, патогенетичну форму СДС, характер і поширеність гнійно-некротичного процесу. Зміни мікрогемодинаміки нижніх кінцівок вивчали за допомогою лазерної доплерівської флоурометрії (ЛДФ).

Моніторинг перебігу ранового процесу доповнювали клінічними, цитологічними, мікробіологічними та морфологічними критеріями за стандартними методиками. Планіметричне дослідження виконували за методикою Л. Н. Попової (1941). Динаміку росту грануляційної тканини та об'єму ранового дефекту визначали гідрометричним методом.

Матеріал для морфологічного дослідження отримували шляхом ексцезійної біопсії під час оперативного втручання або при перев'язках. Виготовлення і забарвлення гістологічних препаратів гематоксиліном i еозином здійснювали за загальноприйнятою методикою, з наступними світлооптичними дослідженнями.

Усі отримані числові результати статистично обробляли за допомогою загальноприйнятих методів, з розрахунком значень критерію Стьюдента, за допомогою комп'ютерних програм S-PLUS 2000, STATISTICA, Excell. Результати вважали достовірними при значеннях р<0,05.

Для накладання вакуумної пов'язки використовували стандартні перев'язувальні набори V.A.C. GranuFoamDressing (USA). Від'ємний тиск створювали за допомогою апарату для вакуумної терапії вітчизняного виробництва фірми «АГАТДНІПРО». Вакуумну терапію ран проводили в режимах від'ємного тиску в межах 80-125 мм рт. ст. у ряді випадків для накладання вакуумних пов'язок використовували запропоновані нами силіконові камери (патент України на корисну модель UA 77350).

Результати й обговорення. Хворим з гострими гнійно-некротичними процесами проводили хірургічне лікуванняу вигляді хірургічних обробок або «малих ампутацій» стопи. Хворим з хронічними ранами проводили хірургічні обробки або механічний дебридимент ран за показаннями. У всіх хворих у наступному застосовували вакуумну терапію ран, яку налагоджували одразу після оперативного втручання (34,5\% хворих) з режимом вакуумування в першу добу 50-80 мм рт. ст. або на наступний день (65,5\% хворих) з режимом 100-120 мм рт. ст.

Використання вакуумної терапії дозволило встановити позитивний вплив на клінічний перебіг ранового процесу, починаючи вже з 2-3 дня лікування. Достовірно купірувався больовий синдром ( $<<0,001)$, зменшувалися прояви гострого запального процесу (купірування набряку, інфільтрації та гіперемії тканин довкола рани) $(p<0,05-0,001)$. Пацієнти відмічали значне покращення загального стану, нормалізацію температури тіла, покращення сну та апетиту, тоді як у контрольних групах ці показники стабілізувалися лише на 5-6 добу лікування.

У хворих з НІФ СДС формування грануляційної тканини розпочиналося з $(4,61 \pm 0,96)$ дня $(p<0,05)$, а до $(6,43 \pm 0,48)$ дня ранові дефекти були готові до проведення автодермопластики (контрольна група - $(9,42 \pm 1,46)$ день). У пацієнтів з ІГФ СДС формування грануляційної тканини розпочиналося з $(6,53 \pm 1,14)$ дня $(p<0,02)$ і рани були готові до пластичного закриття на $(8,76 \pm 1,25)$ день (контрольна група - $(12,48 \pm 1,94)$ день).

Поряд 3 цим відмічалося i достовірне зменшення об'єму ранових дефектів. При НІФ ураження цей показник склав відповідно: після хірургічного втручання - $(18,96 \pm 0,46) \mathrm{cm}^{3}$, на 4-5 день - $(11,14 \pm 0,24) \mathrm{cm}^{3}$ (на 41,24\%), на 7-8 добу - $(5,28 \pm 0,12) \mathrm{cm}^{3}$ (на $\left.72,15 \%\right)(p<0,05)$.

У пацієнтів з ІГФ СДС динаміка зменшення об'єму ран була наступною. Після операції $(16,92 \pm 0,18) \mathrm{CM}^{3}$, на $4-5$ день $-(10,28 \pm 0,24) \mathrm{cm}^{3}$ (на $39,24 \%)$, на $7-8$ день $-(7,82 \pm 0,68) \mathrm{cm}^{3}$ (на $\left.50,63 \%\right)$ $(p<0,05)$.

На момент поступлення у всіх хворих контрольних та основних груп відмічався некротичний або дегенеративно-запальний тип цитограм. Уже на 3 добу лікування у хворих, які отримували вакуумну терапію, з'явився запальний тип цитограм при НІФ у 36,8 \% хворих, а при ІГФ - у 20,3 \% пацієнтів. На 6 добу у 50,0 \% з НІФ і у 3,6 \% з ІГФ ураженням відмічено появу регенераторних типів цитограм, що дозволяє створити сприятливі умови для закриття ран автодермопластикою. На 9 добу відсоток регенераторних типів цитограм склав для НІФ 83,4 \%, для ІГФ - 67,9 \% (контроль - 53,9 \% і 41,6 \%). На 14 добу регенераторні типи цитограм відмічалися у 94,5 \% і 78,6 \% хво- 
Огляди літератури, оригінальні дослідження, погляд на проблему

рих основних груп (контроль - 69,3% і 66,7%) відповідно.

Мікробіологічне дослідження дозволило встановити, що найбільшу частку мікробних угруповань склали стафілококи, мікрококи, коринебактерії, аеробні спороутворювальні бацили, стрептококи, ентеробактерії, псевдомонади, з загальною середньою колонізацією 7,42 lg КУО/г. Використання вакуумної терапії до 6 доби дозволило знизити загальну щільність мікроорганізмів до $(4,19 \pm 0,45)$ l $\mathrm{KУO/г,} \mathrm{що} \mathrm{було} \mathrm{достовірно} \mathrm{ниж-}$ че, ніж у контрольній групі $(5,88 \pm 0,66) \mathrm{lg}$ КУО/г $(p<0,05)$. Відмічалося і значне зменшення видового розмаїття мікроорганізмів у рані.

Використання постійної вакуумної терапії в лікуванні ранових дефектів дозволило значно покращити показники місцевої мікроциркуляції. Вже на 3 добу основні показники зростали у хворих в середньому вдвічі, порівняно з контрольними величинами, і в подальшому утримувалися на цих величинах ( $<<0,05-0,001)$.

Морфологічні дослідження м'яких тканин нижніх кінцівок з ділянок ран пацієнтів на тлі вакуумної терапії дозволило на 5 день констатувати морфологічні зміни тканин, які свідчили про перехід ранового процесу з фази запалення в фазу проліферації. Це дозволяє вже в ці терміни проводити автодермальне закриття ран. На 10 добу використання вакуумної терапії формувався масив грануляційної тканини, морфологічна картина якої на цьому терміні відповідала змінам, які у хворих групи порівняння ми спостерігали на 15 добу лікування.

Аналіз результатів використання вакуумної терапії показав,що майже вдвічі зменшується число етапних некректомій, терміни підготовки ран до автодермопластики скорочуються у хворих 3 НІФ СДС в середньому на $(3,4 \pm 1,2)$ дні, у хворих з ІГФ ураження в середньому на $(3,96 \pm 1,7)$ дні.

Наступним завданням дослідження було вивчити вплив вакуумної терапії на автодермотрансплантати після проведення пластики.

Автодермопластику проводили за методом Тірша додатково перфорованими шкірними клаптями з подальшою вакуумною терапією. Це сприяло кращій фіксації клаптів до рани та забезпечувало адекватну вакуумну евакуацію ексудату. Адгезивність пов'язки до шкіри та від'ємний тиск запобігали можливості зміщення шкірних клаптів, навіть при відповідній руховій активності хворих. Перев'язку проводили один раз на два дні з метою контролю за перебігом ранового процесу.

Використання вакуумної терапії сприяє видаленню надлишкової рідини з інтерсиціального простору, що стимулює мікроциркуляцію та позитивно впливає на подальшу фіксацію та при- живлення шкірних клаптів. Це стверджується і даними ЛДФ. На тлі вакуумної терапії основні показники мікроциркуляції на краю рани утримуються в межах, майже вдвічі вищих від нормальних величин, як для гострих, так і для хронічних ран $(p<0,05-0,001)$.

Реєстрація показників мікроциркуляції за допомогою ЛДФ на пересаджених шкірних клаптях показала, що на тлі вакуумної терапії на другу добу лікування дані не визначалися як в контрольних, так і в основних групах. Однак вже на 3-4 добу лікування вакуумом з'являлися показники ЛДФ у пересаджених клаптях шкіри у хворих основних груп, хоча вони мали спотворений характер. У хворих контрольних груп показники ЛДФ не визначалися. На 5-6 добу лікування у хворих основних груп визначалися показники мікроциркуляції, які в цифрових значеннях були нижчими від контрольних показників, що може свідчити про повну фіксацію пересадженої шкіри. У пацієнтів контрольних груп показники ЛДФ лише з'являлися. Це свідчить про кращі умови та стимуляцію процесу приживлення шкірних клаптів на тлі вакуумної терапії. У жодному випадку використання вакуумної терапії ми не відмітили зміщення або відшарування шкірних клаптів. Проведення перев'язок щоденно або через день та динамічний контроль за перебігом ранового процесу дозволяють запобігти зміщенню та лізису шкірних трансплантатів. Забезпечити часті перев'язки зі здешевленням лікування дозволяє використання вакуумних силіконових камер.

Хорошим результат вважали при приживленні шкірних клаптів не менше ніж на $90 \% 3$ наступною повною епітелізацією рани. Задовільним - пригоєння клаптів на 50-90 \% з можливістю подальшого самостійного загоєння рани шляхом епітелізації. Незадовільним - пригоєння клаптів менше ніж на $50 \%$.

У хворих на НІФ СДС загальний відсоток ускладнень у контрольній групі з гострими ранами склав 45,5 \%, а у хворих основної групи $24,1 \%$ що на 21,4 \% менше. При хронічних ранах відповідні показники склали 55,5 \% і 38,8 \%, що менше на $16,7 \%$.

У хворих на ІГФ СДС відсоток ускладнень у контрольній групі пацієнтів з гострими ранами склав 83,3 \%, в основній - 32,3\%, що на 51,0\% менше. При хронічних ранах ці показники склали для контрольної групи 66,6 \%, для основної $51,8 \%$, що менше на $14,8 \%$.

у загальному у хворих на НІФ з гострими ранами хороший результат автодермопластики отримано у 24 (61,5 \%), а задовільний - у 15 $(38,5$ \%) хворих. Для хронічних ран результати автодермопластики склали: хороший -у 21 (67,7 \%), 
Огляди літератури, оригінальні дослідження, погляд на проблему

задовільний - у 10 (32,3 \%) пацієнтів. Незадовільних результатів у цій групі хворих не було.

У пацієнтів з ІГФ СДС хороший результат автодермопластики при гострих ранах отримано у 18 (50,0 \%) хворих, задовільний - у 13 (36,1\%), незадовільний - у 5 (13,9\%) пацієнтів. При хронічних ранах ці показники склали: хороший результат -у 19 (52,8 \%), - задовільний - у 11 (30,5\%), незадовільний - у 6 (16,7 \%) пацієнтів.

Це дозволило скоротити терміни стаціонарного лікування хворих з НІФ СДС в середньому на $(4,3 \pm 1,7)$ ліжко-дні, хворих на ІГФ - на $(4,1 \pm 1,9)$ ліжко-дні.

Висновки. 1. Вакуумна терапія ран у хворих на СДС сприятливо впливає на перебіг ранового процесу і $\epsilon$ ефективним методом лікування, який можна рекомендувати для використання у вищеозначених хворих.

2. Вакуумна терапія дозволяє майже вдвічі зменшити число етапних некректомій та скороти- ти терміни підготовки ран до автодермопластики у хворих з НІФ СДС в середньому на $(3,4 \pm 1,2)$ дні, у хворих з ІГФ - в середньому на $(3,96 \pm 1,7)$ дні.

3. Використання вакуумної терапії після проведення автодермопластики сприяє кращій фіксації і швидшому приживленню автодермотрансплантатів та запобігає розвитку їх лізису.

4. Використання вакуумної терапії ран дозволяє скоротити терміни стаціонарного лікування хворих з НІФ СДС в середньому на $(4,3 \pm 1,7)$ ліжко-дні, хворих на ІГФ - на $(4,1 \pm 1,9)$ ліжко-дні, що має не тільки медичне, а й соціальне значення.

Перспективи подальших досліджень. В перспективі планується провести дослідження 3 метою встановлення оптимальних диференційованих методик та режимів проведення вакуумної терапії ран у хворих на СДС залежно від патогенетичної форми ураження та характеру перебігу ранового процесу.

\section{ЛІТЕРАТУРА}

1. Хирургическое лечение синдрома диабетической стопы, осложненного гнойно-некротическими процессами / Ю. Г. Шапкин, Е. В. Ефимов, А. В. Хорошкевич, А. Ю. Хромых // Новости хирургии. - 2012. - Т. 20, № 6. - C. 12-16.

2. Minor amputation in patients with diabetes mellitus and severefoot ulcer sachieves goodout comes / H. Svensson, J. Apelqvist, J. Larsson [et al.] // J. Wound Care. - 2011. - Vol. 20, № 6. - P. 261-266.

3. Torre J. I. Woundhealing, chronicwounds / J. I. Torre, J. A. Chambers [Electronic resourse]. - 2008. - Mode of access: of acess: 10.01.2011.

4. Рисман Б. В. Дифференцированная тактика закрытия послеоперационных дефектов кожи у пациентов с гнойно-некротическими осложнениями синдрома диабетической стопы / Б. В. Рисман // Новости хирургии. - 2011. - Т. 19, № 2. - С. 66-71.

5. Ксено- та аутодермопластика в лікуванні ран у хворих на цукровий діабет / Я. Й. Крижановський,
В. С. Кульбака, С. Л. Кіндзер [та ін.] // Вісник Української медичної стоматологічної академії. - 2007. - Т. 7, Вип. 1-2. - С. 232-237.

6. Павлышин А. В. Пластическое закрытие ран и трофических язв рельефным аутодермотрансплантатом у больных с синдромом диабетической стопы / А. В. Павлышин, В. А. Шидловский, П. А. Герасимчук // Вестник Российской академии медицинских наук. 2013. - № 1. - С. 72-75.

7. Вакуум-інстиляційна терапія у хворих синдромом діабетичної стопи / О. М. Бєсєдін, Ю. Ю. Малюк, Л. І. Карпенко [та ін.] // Клінічна хірургія. - 2014. № 11 (3). - C. 8-10.

8. Comparision of vacuum-asisted closure and moist wound dressingin the treatment of diabetic foot ulcers / H. Ravari, M. H. Modaghegh, G. H. Kazemzadeh [et al.] // J. Cutan. Aesthet. Surg. - 2013. - Vol. 6, № 1. - P. 17-20.

\title{
AUTODERMOPLASTY AND VACUUM THERAPY IN WOUNDSIN PATIENTS WITH DIABETIC FOOT SYNDROME
}

\author{
@P. O. Herasymchuk, V. H.Vlasenko, A. V. Pavlyshyn, D. B. Fira
}

\section{Horbachevsky Ternopil State Medical University}

SUMMARY. Base dont heexamination and treatment of 142 patients with complicated forms of diabetic foot syndrome, the influence of vacuum therapy on wounds during preparation for autodermoplasty proved that vacuum therapy of wound sallowedal most half reduction in the number of landmark necrectomy. It also reduced the time of preparation for autodermoplasty in patients with neuropathic-infected (lesions form) on anaverage of (3.4 \pm 1.2 ) days, in patients with is chemic-gangrenous formon anaverage of $(3.96 \pm 1.7)$ days. This allowsyoutoreduce the time of admission of patients (bed days) by anaverage of $(4.2 \pm 1.8)$, which is not of medical valuebutal sosocial value.

KEY WORDS: Diabetic foot syndrome, vacuum therapy. 